\section{| RESUMEN}

Patrik Schumacher es socio de Zaha Hadid Architects, director del Design Research Lab (DRL) de la Architectural Association en Londres y profesor en varias universidades europeas. Durante más de 15 años ha desarrollado estas tres actividades en forma paralela lo que ha permitido pensar, experimentar y hacer arquitectura con una postura de vanguardia. Esta experiencia lo impulsó a escribir LA AUTOPOIESIS DE LA AROUITECTURA, Un extenso tratado -como él lo ha definido- cuyo objetivo principal es presentar un discurso global de la arquitectura, generado al interior de la disciplina. Escritos, conversaciones cara a cara con profesores, estudiantes, colegas y Zaha Hadid fueron su estímulo. Los trabajos del sociólogo alemán Niklas Luhmann y los biólogos chilenos Humberto Maturana y Francisco Varela, la inspiración decisiva. «Sé que es un libro de mayor significancia para los arquitectos, pero creo que también debiera de captar la atención de otras disciplinas interesadas en entender la arquitectura como una expresión cultural contemporánea». señala.

\section{| ABSTRACT |}

Patrik Schumacher is partner at Zaha Hadid Architects, director of the Design Research Lab (DRL) at the Architectural Association School of Architecture in London and professor in several European universities. During almost 15 years he has developed these activities in parallel, which has enabled him to think experiment and practice architecture on the avant-garde side. This experience encouraged him to write The Autopolesis of ArChiteCture. This is a comprehensive treatise -he stated- whose main purpose is to attempt a complete discourse analysis of architecture. His stimulus was an amalgam of writings and face to face conversations with students, professors, colleagues, and partner Zaha Hadid. However the crucial inspiration came from outside architecture, from the work of sociologist Niklas Luhmann and the Chilean biolooists Humberto Maturana y Francisco Varela. He stated: «The book, although of true significance to architects, might also be able to resonate within different disciplines interested in architecture and design as expressions of contemporary cultures.

\title{
Entrevista. La autopoiesis de la arquitectura
}

P. Sch.: Antes de comenzar la entrevista y contestar tus preguntas, quisiera expresar mi admiración por el trabajo de Humberto Maturana y Francisco Varela. El concepto de autopoiesis y la expansión del concepto de cognición de Maturana, ha sido extraordinariamente productivo. Lo mismo aplica para el concepto de mente encarnada (embodied mine) de Varela.

—L. F.: Usted ha señalado que el espíritu y misión de su libro «La Autopoiesis de la Arquitectura» es producir un impacto en la arena arquitectónica por medio de la presentación de un sistema teórico integral. ¿̇Cuál es la importancia de esta sistematización y cuáles son las implicancias en la escena arquitectónica contemporánea?

P. Sch.: La necesidad urgente de una nueva sistematización de los recursos intelectuales de la disciplina, está relacionada con la ambición de estimular la actual convergencia de la vanguardia -el Parametricismo- dentro de las corrientes principales de pensamiento actuales. Liderar estas corrientes, implica tomar toda la responsabilidad en el desarrollo profundo del medio ambiente construido. Esto requiere un razonamiento exhaustivo y la reafirmación de los valores fundamentales, métodos y repertorios de la arquitectura, sobre la base del entendimiento de su función social, y reflexionar además, acerca de cómo esta función propone tareas concretas en el contexto histórico actual: Una sociedad de redes Posfordista.

El hecho es que la autopoiesis de la arquitectura -arquitectura como discurso, disciplina académica y profesión- no ha estampado su sello en el medio ambiente construido global desde la desaparición del Modernismo. Treinta años de experimentación de vanguardia arquitectónica, tienen todavía que producir resultados que impacten

* Patrik Schumacher. Estudió Filosofía y Arquitectura en Bonn, Londres y Stuttgart, donde recibió su Diploma de Arquitectura en 1990. En 1999 completó su Doctorado en el Instituto de Ciencias Culturales de la Universidad de Klagenfurt. Se unió a Zaha Hadid Architects en 1988 y es actualmente socio de la oficina.

En 1996 junto a Brett Steele, fundó el «Laboratorio de Investigación en Diseño» (Design Research Laboratory -DRL-) en la Architectural Association en Londres, del cual continúa siendo codirector. Desde 2004, es Profesor en el Institute for Experimental Architecture en la Universidad de Innsbruck y actualmente es profesor invitado en la Universidad de Artes Aplicadas de Viena. Su extenso trabajo teórico está disponible en www.patrikschumacher.com

** Loreto Flores es Arquitecto de la Universidad de Chile y MArch Design Research Lab de la Architectural Association School of Architecture (AA). Su trabajo ha sido expuesto en la Bienal Internacional de Arquitectura de Beijing, AA Projects Review y AA Open Jury, en Londres y publicado en AD Magazine, «Collective Intelligence in Design» (2006) y «Architextiles» (2006). «Netlab», su tesis de Máster fue galardonada con el FEIDAD Design Merit Award 2006. Desde ese mismo año trabaja en Zaha Hadid Architects, donde ha colaborado en diversos concursos y proyectos en Francia, España, China, Singapur y Egipto. 


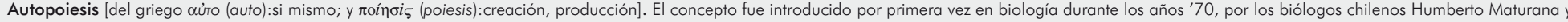
Francisco Varela, para designar la capacidad de los organismos vivos de autoproducirse, es decir, que estos sistemas pueden crear o destruir elementos al interior de sí mismos como respuesta a los estímulos de su medio. Posteriormente, el término ha sido utilizado en otras disciplinas, como por ejemplo sociología, por el alemán Niklas Luhmann.

Referencias: Maturana H.R. y Varela F.J. Autopoiesis y cognición. Dordrecht, Holanda: D. Reidel, 1980. / Luhmann, N.R. Organización y decisión, autopoiesis y entendimiento comunicativo. Barcelona: Anthropos, 1997.

Parametricismo. Fue introducido por Patrik Schumacher durante la Bienal de Arquitectura de Venecia 2008, para designar-de acuerdo a su tesis-al estilo que sucede al Modernismo. El nombre se deriva de la idea de que los elementos empleados en el proceso de diseño pueden ser entendidos como parámetros o variables capaces de ser manejadas y modificadas de manera tal de producir no solo un producto final, sino una serie de iteraciones durante el proceso, que pueden ser considerados también, como diseños en sí mismos. Por lo tanto, el Parametricismo promueve la diferenciación por sobre la repetición. En lugar de las figuras geométricas clásicas: cubos, rectángulos, cilindros, pirámides y esferas, sus figuras primitivas provienen del modelamiento de subdivisión de superficies y modelamiento desde NURBS (Non-Uniform Rational B-Splines), sistemas dinámicos de fluidos, pelo y tejidos (fluids, hair and cloth).

Referencias: Schumacher, P. "Parametricismo: un nuevo estilo global para la Arquitectura y el Diseño Urbano". En: Leach, N. (Ed.). AD Digital Cities 2009; 79(4). / http://www.patrikschumacher.com/Texts/Parametricism\%20 as $\% 20$ Style.htm

decisivamente al mundo. Mi tratado, integral y sistemático debiera estimular y guiar a la vanguardia actual para intentar alcanzar la hegemonía de las corrientes principales de la arquitectura

-L. F.: Si la arquitectura está constituida por un discurso propio y autónomo, ìpor qué la decisión de usar términos provenientes de otras disciplinas?, ¿̇cuál es la ventaja de entender la arquitectura como un sistema autopoiético?

P. Sch.: La autonomía de la arquitectura significa autodeterminación en el discurso. $\mathrm{Ni}$ filósofos, científicos, políticos o clientes pueden gobernarla. La disciplina es autónoma en su esfuerzo por mantenerse relevante y productiva; pero al mismo tiempo, para sobrevivir, debe permanecer relevante y productiva para la sociedad. Esto es lo que Luhmann llama «apertura por medio del cierre» («openness through closure»). La disciplina tiene que observar e interpretar su medio ambiente social para responder pertinentemente con sus propios términos. La abstracción autorreferencial de la autopoiesis, es una condición preexistente para respuestas más sofisticadas y productivas a los desafíos de la sociedad.

Una relación similar de observación e interpretación existe también entre arquitectura y filosofía y entre arquitectura y ciencia. La arquitectura observa estas disciplinas en busca de inspiración y guía para actualizar sus propias capacidades intelectuales. La filosofía es un recurso especialmente importante. De hecho, esta actúa como un centro de intercambio de recursos intelectuales, esquemas conceptuales, principios metodológicos, etc. y los filósofos son los que abstraen y generalizan esquemas y metáforas más avanzados desde varias disciplinas individuales.

La Arquitectura no se puede excluir de este desarrollo intelectual general. Sin embargo, cuando adopta conceptos y argumentos lo hace sobre la base de sus propias necesidades, intereses y criterios de relevancia. La adopción es así una interpretación-adaptación. Lo que cuenta es que los términos importados tengan sentido dentro del campo de estudio; es decir, dentro del discurso autopoiético de la disciplina, sin apelar a autoridades externas.
Lo mismo aplica a la adopción específica del concepto de autopoiesis en mi discurso. Las respuestas dentro de la arquitectura son las que importan ahora, no la autoridad de expertos en la teoría de autopoiesis fuera de la arquitectura. Esta postura es la misma que Luhmann formuló a través de su apropiación del concepto de autopoiesis en sociología. Ciertamente, la autodescripción arquitectónica sobre la base de la teoría de la comunicación es un aporte de la teoría de la sociedad de Luhman.

Acerca de las ventajas de usar el concepto como base para una autodescripción de arquitectura, estas no pueden ser resumidas en pocas palabras. Finalmente serán los logros y éxitos del libro los que dirán.

-L. F.: Usted ha señalado que «el intento de construir una teoría unificada cruzando un campo de teorías específicas tiene como objetivo testear la consistencia de este. ¿̇Cuál es su primera conclusión acerca de esto después de haber terminado el primer volumen de su libro?

P. Sch.: No, una teoría unificada no puede probar la consistencia del campo completo, sino solo testear las perspectivas e ideas del autor o quizás las ideas de cierto movimiento. No obstante, la arquitectura es un sistema de comunicaciones individual, está llena de opiniones y teorías en conflicto y un sistema de este tipo existe en la medida que todos estos elementos se referencien y debatan entre sí. Un sistema teórico unificado es otro tema. Se trata de seleccionar un subconjunto coherente dentro de la totalidad de teorías en circulación y abarcar todos los aspectos, cuestionamientos y tareas de la disciplina. Pienso que, hasta que mi teoría sea cuestionada y desmentida, he tenido éxito en construir una teoría unificada en ese sentido y el punto central de esta, es la explicación de la función social de la arquitectura.

-L. F.: «Una perspectiva global y coherente es lo necesario para ofrecer un liderazgo efectivo a una firma que busca innovar a través de un amplio espectro de tareas programáticas. $\dot{2}$ Es esta falta de coherencia lo que ha reducido la importancia de los arquitectos en los procesos urbanos contemporáneos? ¿̇Cómo concibe nuestro rol como profesionales hoy en día?
PATRIK SCHUMACHER [P. Sch.]* in conversation with LORETO FLORES [L. F.] ${ }^{* *}$

\section{Interview. The autopoiesis} of architecture

\section{P. Sch.: Before answering your interesting and insightful questions I would like to express my admiration of the work of Maturana and Varela. The concept of autopoiesis and Maturana's expansion of the concept of cognition has been extraordinarily productive. The same goes for Varela's concept of the embodied mind.}

- L. F: You have stated that the spirit and mission of «The Autopoiesis of Architecture» is to produce an impact in the architectural arena by the presentation of a comprehensive theoretical system. Why is important to create this systematization and which are the implications in today's international architectural scene?

P. Sch.: The urgent need for a new great systematization of the discipline's intellectual resources is related to the ambition to push the current convergence in architecture's avant-garde -Parametricism- into the mainstream. Going mainstream implies taking full responsibility for the further development of the built environment. This requires a comprehensive reflection and reassurance of architecture's fundamental values, methods and repertoires, on the basis of an understanding of architecture's societal function. This also requires us to theorize how this general

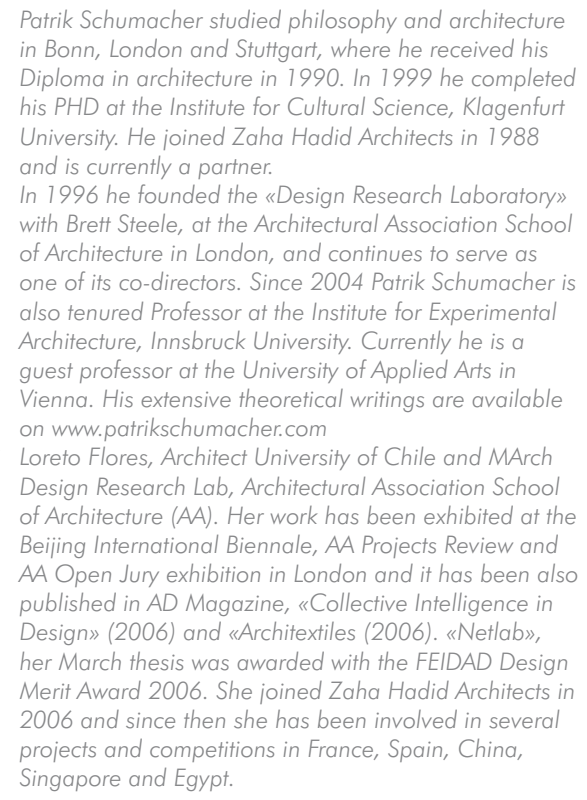




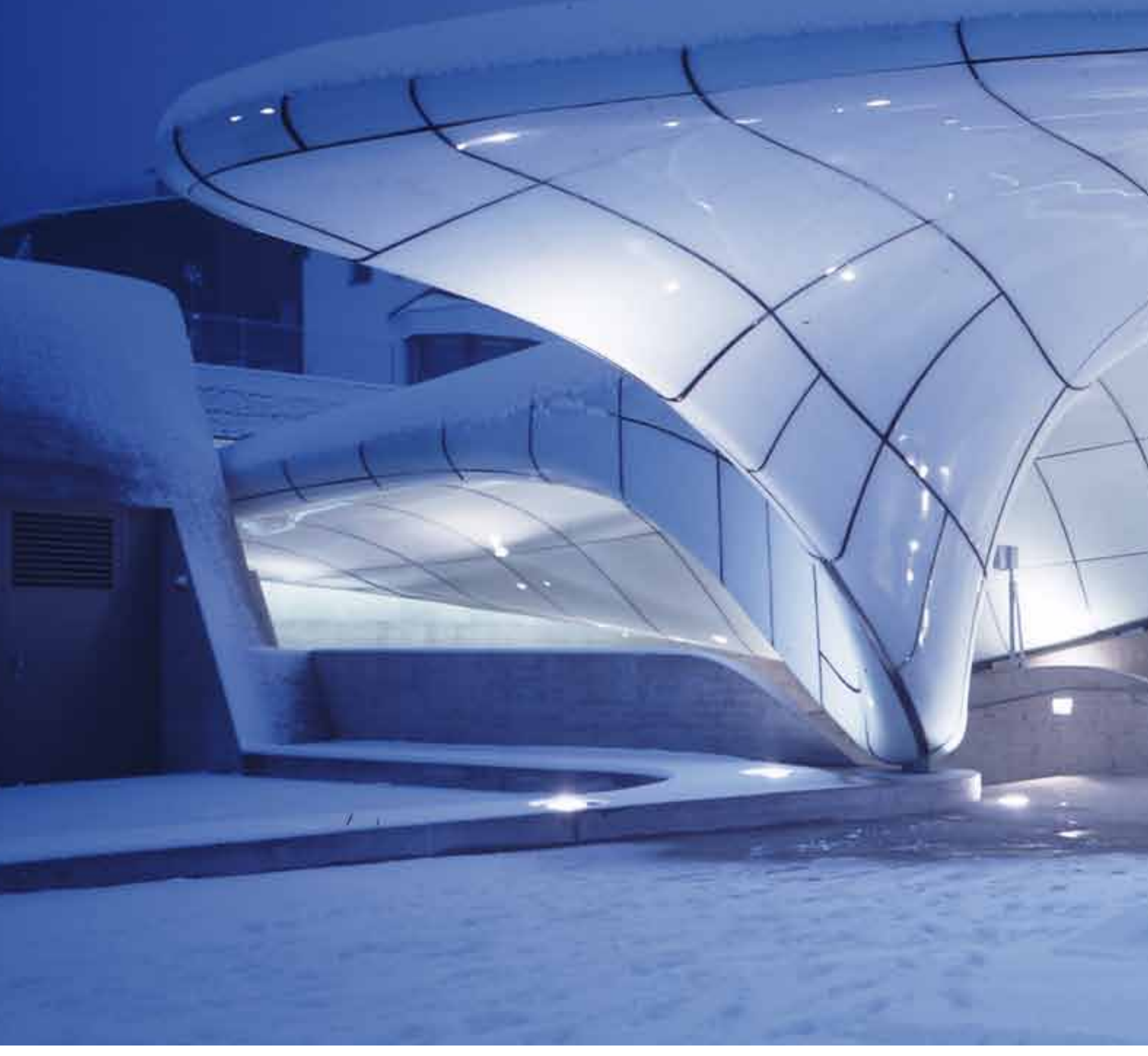


1. Estación Hungerburg-NordPark Cable Railway. Innsbruck, Austria. Zaha Hadid Architects. Photography Werner Huthmacher.

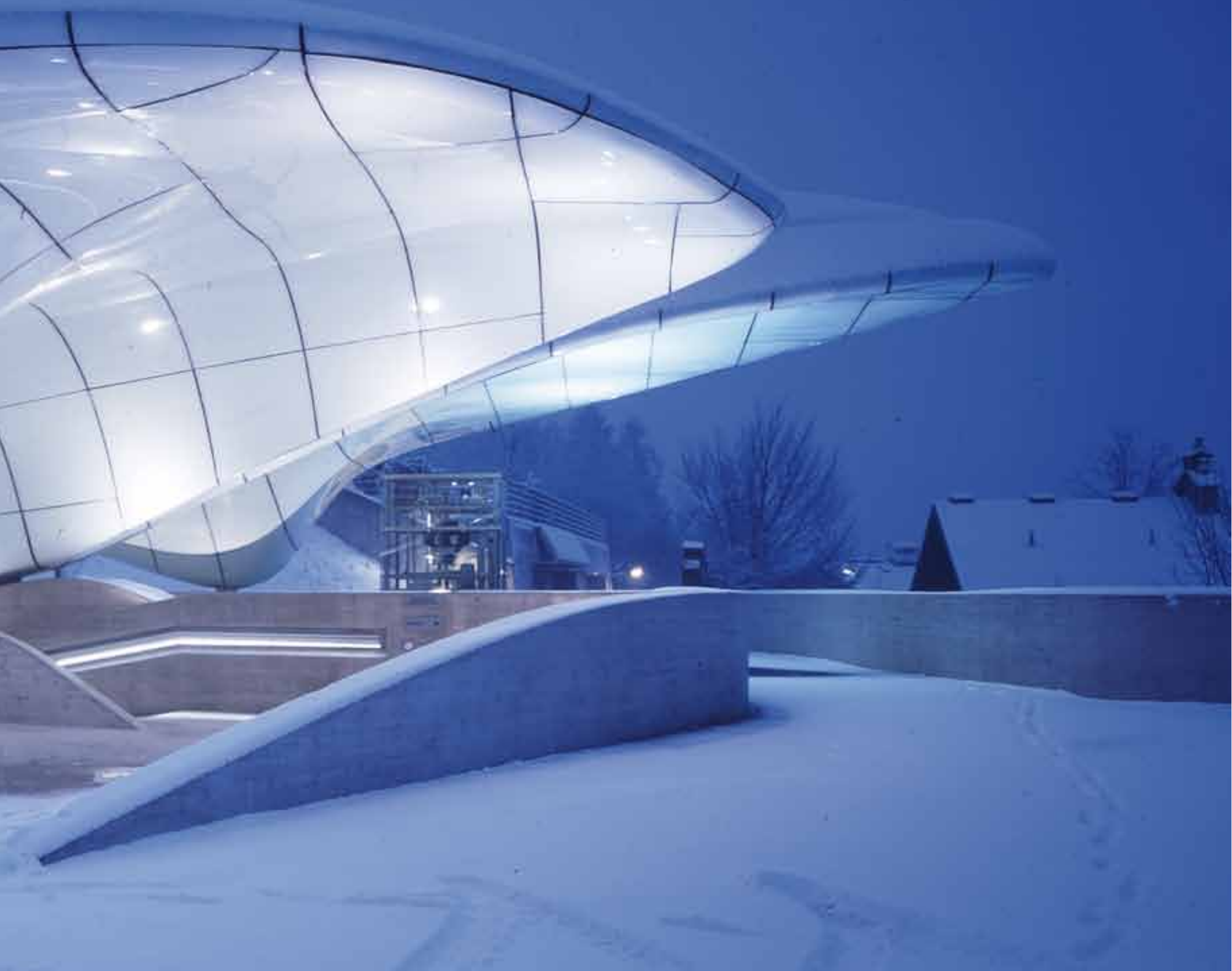


function poses concrete tasks in the current historical context: Post-fordist network society.

The fact is that the autopoiesis of architecture architecture as discourse, academic discipline and profession- has not stamped its imprint on the global built environment since the demise of Modernism. Thirty years of experimentation in the avant-garde segment of architecture have yet to produce results that decisively impact world civilization.

My systematic and comprehensive treatise is supposed to embolden and guide the current avant-garde in making a bid for mainstream hegemony.

-L. F.: If architecture is constituted by its own autonomous discourse, Why the decision of using terms from other disciplines? Which is the advantage of understanding architecture as an autopoietic system?

P. Sch.: Architecture's autonomy implies architecture's discursive self-determination. Neither philosophers, scientists, politicians, nor clients, can command architecture. The discipline is autonomous in its effor to keep itself relevant and productive. However, in order to survive the discipline indeed has to stay relevant and productive for society. This is what Luhmann terms «openness through closure». The discipline has to observe and interpret its societal environment, in order to respond pertinently, on its own terms. Autopoiesis, self-referential closure, is a precondition for more sophisticated, productive responses to the challenges of society. A similar relationship of observation and interpretation holds also between architecture and philosophy, as well as between architecture and science. Architecture observes these disciplines with a view towards finding inspiration and guidance for upgrading its own intellectual capacities. Especially philosophy is a great resource. In fact, philosophy acts as an intellectual exchange hub for intellectual resources, for conceptual schemata, methodological principles etc. Philosophers abstract and generalize the most advanced schemata and tropes from the various individual disciplines. Architecture cannot insulate and exclude itself from the general intellectual development. However, when it adopts concepts and forms of argumentation it does so on the basis of its own needs, interests and criteria of relevance. Adoption is here always interpretation and adaptation. What counts is that the imported concepts make sense within the field. This is judged internally, within the autopoietic discourse of the discipline, without appeal to outside authority. The same applies to the specific adoption of the concept of autopoiesis in my discourse. The responses within architecture matter now, not the authority of experts on auotopiesis theorist outside of architecture. This stance and insight is the very insight/stance Luhmann formulated via his appropriation of the autopoiesis concept into sociology. What the advantages are of using the concept as basic concept within an architectural self-description cannot be summed up in a few words. Certainly, architectural self description on the basis of communication theory benefits from the theoretical power of Luhmann's theory of society. Ultimately the achievement/success of the book as a whole must tell us.

- L. F.: You mentioned that «the attempt to construct a unified theory across a field of special theories is testing the field for consistency» What is your first conclusion about this after you have finished the first volume of the book?

P. Sch.: No, a unified theory is not testing the whole field for consistency; it can only test the author's views and ideas or perhaps a certain movement's ideas. Although architecture is a single system of communications it is full of conflicting opinions and theories. A system of communications exists as long as all these conflicting communications and contradictory theories reference each other and debate with each other. A unified theoretical system is another matter. It is a matter of selecting a coherent subset from the totality of circulating theories. This subset should be comprehensive in the sense of covering all aspects, questions and tasks of the discipline. believe, until challenged and proven wrong, that I have succeeded in constructing a unified theory in this sense. The lynchpin of the system is the explication of architecture's societal function.

-L. F: «A comprehensive and coherent perspective is what is required to offer effective leadership to a large firm working innovatively across the full spectrum of programmatic tasks» Is this lack of coherence what has reduced the importance of architects in contemporary urban process? How do you conceive our role as professionals nowadays?

P. Sch.: Yes, this is my assessment. Architecture lacks impact and importance because our avant-garde is not yet fully geared up to make its mark globally. A confident, comprehensive and coherent perspective is what is required to regain impact and importance. Within Zaha Hadid Architects we have achieved a coherent agenda of innovation across programmes and scales. But a single firm, or a small group of firms, cannot shift the physiognomy of the global built environment. We need the discipline as a whole -or at least significant segments of it- to progress in the direction mapped out by us and others working within the new paradigm of Parametricism.

- L. F: "Architecture as a system of communications is neither a mere collection of artifacts, nor a mere form of knowledge, nor merely a particular professional practice. Rather it encompasses all three categories: artifacts, knowledge and practices, all understood as communications that connect to each other in an ongoing recursive network». However our way to communicate with society and as you also said our way to serve society is trough buildings. How can we also give importance to our theoretical discourse?

P. Sch.: Architectural theory is only for architects, it is a part of architecture's internal discourse.
P. Sch.: Sí, esa es mi evaluación. La arquitectura carece de impacto e importancia porque nuestra vanguardia no está completamente preparada para provocar interés global. Una perspectiva convincente, integral y coherente es lo que se requiere para recobrar valor y trascendencia. Al interior de Zaha Hadid Architects hemos logrado una agenda de innovación congruente a través de diferentes programas y escalas. Pero solo una firma o un pequeño grupo de ellas, no puede cambiar la fisonomía del medio ambiente construido global. Necesitamos la disciplina como un todo -o por lo menos segmentos significativos de esta- para progresar en la dirección trazada por nosotros y otros, trabajando de acuerdo al nuevo paradigma del Parametricismo.

\section{-L. F.: La arquitectura como sistema de} comunicaciones no es una mera colección de artefactos, forma de conocimiento o práctica profesional particular; sino más bien, abarca estas tres categorías: artefactos, conocimiento y prácticas, entendidas como comunicaciones que se conectan entre sí, en una red recursiva en constante desarrollo. Sin embargo, nuestra forma de comunicarnos y servir a la sociedad es a través de edificios. ¿̇ómo podemos otorgar además importancia a nuestro discurso teórico?

P. Sch.: La teoría arquitectónica es solo para arquitectos, es parte del discurso interno de esta. No espero que una audiencia más amplia se interese en ella. Es ciertamente un discurso para expertos y por ello escribí mi libro solo para arquitectos y teóricos de arquitectura (además de diseñadores). El público general no tiene necesidad de entender la teoría, ya que los arquitectos se comunican con él a través de edificios y espacios diseñados. Estos constituyen un tipo de comunicación muy específico: actúan como instancia e invitación para una interacción cara a cara entre personas presentes en el mismo espacio. La función social del diseño urbano y arquitectónico es entonces, enmarcar la comunicación social de forma innovadora.

-L. F.: De acuerdo a la teoría de autopoiesis de la arquitectura, la antigüedad clásica marca la primera aparición de la arquitectura, pero es el Renacimiento Italiano el momento histórico que define el verdadero comienzo de la 
2. Estación Alpenzoo-NordPark Cable Railway. Innsbruck, Austria. Zaha Hadid Architects. Photography Werner Huthmacher.

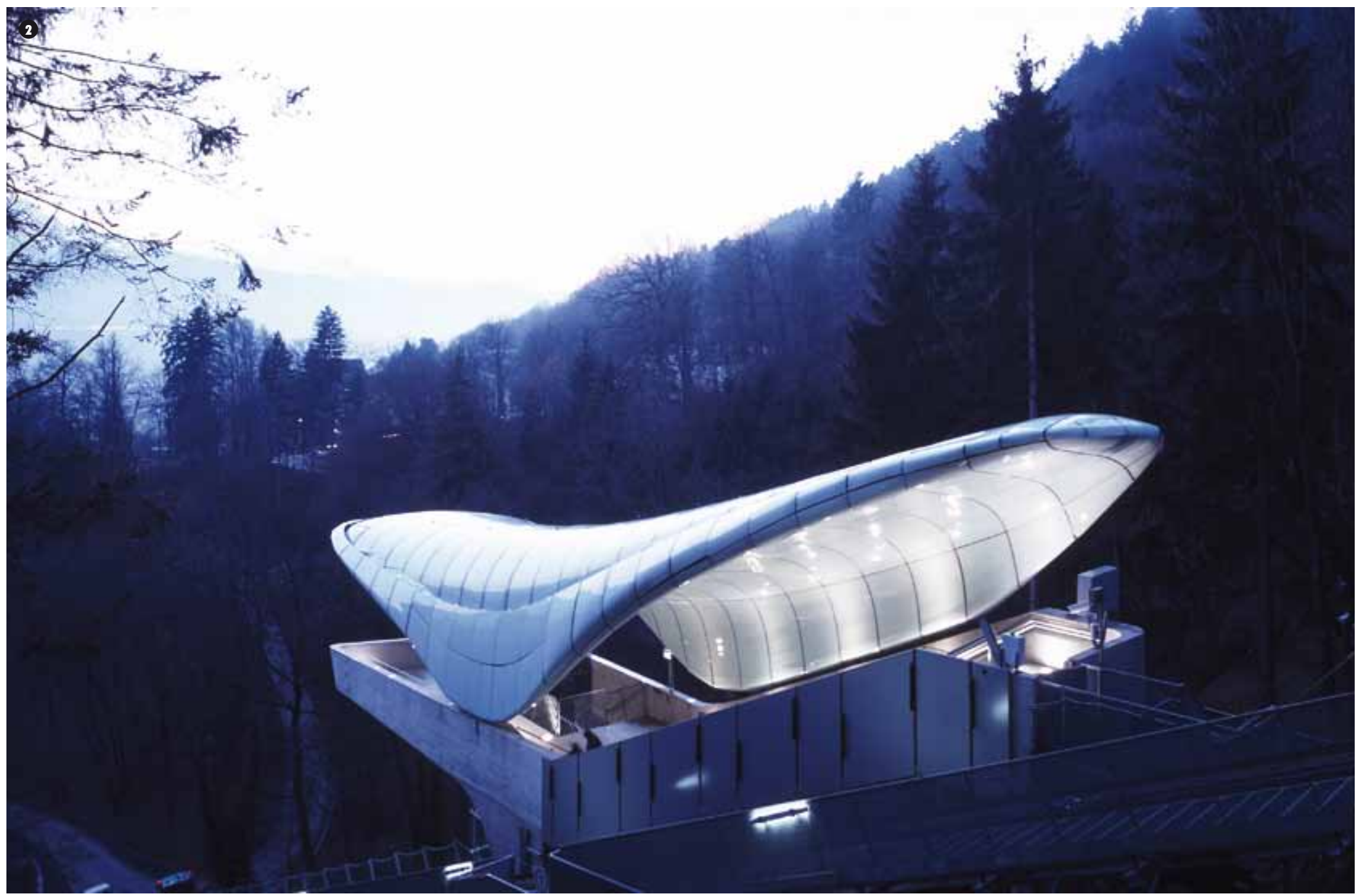

autopoiesis de la arquitectura. ¿̇Considera que las construcciones vernaculares son parte del sistema autopoiético de la arquitectura?

P. Sch.: No, las construcciones vernaculares no pertenecen a la arquitectura. Yo distingo estrictamente entre edificios subordinados a la tradición y arquitectura como disciplina teórica e innovadora, basada en la separación de diseño y construcción. Dicha separación ocurrió en el Renacimiento Italiano, solo entonces el diseño arquitectónico emergió acompañado de dibujos, teoría y arquitectos-autores. Este fue el big bang de la arquitectura, ocasionando una enorme aceleración en la evolución del medio ambiente construido en concordancia con el desarrollo de la sociedad. Nunca antes los edificios fueron diseñados y discutidos completamente sobre papel y el uso de este medio y de la perspectiva, facilitó la aparición de un discurso crítico y especulativo en diseño.

Por otro lado, los edificios son comunicaciones arquitectónicas solo en la medida en que respondan y estén incorporados al discurso de la disciplina. En este sentido, una estructura o sistema de construcción vernacular-aunque no es arquitectura per se- puede ser incluida en el discurso, solo si un arquitecto o teórico refiere a esa estructura dentro de su discurso; esto sucedió por ejemplo, cuando Bernard Rudofsky publicó su libro ARQUITECTURA SIN ARquITECTOS. Se requiere de un arquitecto o de un teórico para incluir edificios vernaculares dentro del dominio de la arquitectura. No puede haber arquitectura sin autor como punto de referencia.

-L. F.: ¿Por qué las Escuelas de Arquitectura debieran transformarse en laboratorios experimentales? ¿Cuál es su rol dentro de la autopoiesis de la arquitectura?

P. Sch.: El rol de algunas escuelas de arquitectura (no todas) es desarrollar investigación en diseño arquitectónico y contribuir, de esta forma, a la vanguardia de la disciplina. (Aquellas escuelas que simplemente otorgan capacitación sin una contribución innovadora pertenecen al sistema de educación más que a la arquitectura). Ya que no existen 
I do not expect that a broader audience takes much interest in architectural theory. Architectural theory is an expert discourse. I wrote my book for architects and architectural theorists only (as well as for all designers). There is no need for the general public to understand architectural theory. Architects communicate to wider audiences via buildings and designed spaces. Buildings and spaces constitute a very specific type of communication: they are ordering and framing communications that act as framing premises and priming invitations for (face to face) communicative interaction between people co-present in space.

The societal function of urban and architectural design is the innovative ordering and framing of social communication

\section{-L. F.: According to the theory of architectural} autopoiesis, classical antiquity marks the first emergence of architecture but the Italian Renaissance is the historical moment that marks the true onset of the autopoiesis of Architecture. Following this, Do you consider vernacular constructions as part of the autopoietic system of architecture?

P. Sch.: No, vernacular constructions do not belong to architecture. I strictly distinguish between tradition bound building and architecture as an innovative, theory-led discipline based on the separation of design and construction. This separation happened with the Italian Renaissance. Only then did architectural design emerge together with drawing, theory and named architect authors. This was the big bang of architecture's arrival delivering an enormous acceleration of the evolution of the built environment in line with the rapid development of society. Never before were buildings fully designed and discussed on paper. The move into the medium of paper and the utilization of perspective allowed for the emergence of a critical, speculative design discourse. Buildings are architectural communications only insofar as they are embedded in and respond to the discipline's discourse.

A vernacular structure or system of construction

-although per se not architecture- can be brought into the discourse if an architect or architectural theorist references such structures within his/her discourse. This happened for instance when Bernard Rudofsky published his book «Architecture without Architects». It takes an architect or architectural theorist to bring vernacular buildings into the domain of architecture. There can be no architecture without architect/author as its point of reference.

-L. F.: Why should Architecture Schools become experimental laboratories? What is their role within the autopoiesis of architecture?

P. Sch.: The role of some (but not all) architecture schools is to conduct architectural design research and so to contribute to architecture's avant-garde segment. (Those schools that are merely providing training without innovative contribution belong to the education system rather than to architecture.) Since there are no dedicated research institutes within architecture it is the schools as well as avant-garde firms that have to take on the task of research and experimentation. Only via the differentiation into avant-garde and mainstream can architecture cope with the accelerating demand/ pressure for future adaptive innovations while delivering established state of the art practice with respect to all immediate tasks.

-L. F.: «The limits of our design language are the limits of our design thinking. How we represented architecture determines how we anticipate (design) architecture». Is Parametricism the latest extension of our limits of architectural thinking and also designing?

P. Sch.: No, Parametricism is a style rather than a design medium. It is the design medium that defines the limits of our design thinking. However, Parametricism depends on the new design media and it is (therefore) the style that makes the most of the expanded universe of possibilities afforded by the new media. The new computational design media have indeed shifted and expanded the limits of our design thinking. I am talking about subdiv and nurb modeling, about dynamical (quasi-physical) systems like fluids, hair dynamics or cloth. More importantly, I am talking about the whole world of associative modeling. The idea and possibility of scripting associations (dependencies) between the variables of a parametric model opens up a whole new universe of design thinking, the thinking in terms of variations and correlations, as well as in terms of geno-types that contain the virtuality of an infinite variety of pheno-types. The very status and meaning of a design representation or model changes: it is just a fleeting moment or point in a co-present continuum of possibilities, a pheno-type of an underlying genotype that is the topological and logical structure of the model.

-L. F.: If Parametricism produces an open and more flexible design process; Can it be recognized as a more democratic way to design? Which are the differences with Modernism?

P. Sch.: I would not say that Parametricism is a more democratic way of design. I'd rather say it is a more versatile and adaptive way of design. It can (but must not) work via bottom up, emergent processes, e.g. when using generative scripts or agent based systems. Modernism is always a deliberate top down process, whether it is moving via aggregation from the inside out or via substraction and division from the outside in Modernism's compositional primitives are the same as those of classical architecture: rigid geometric figures like cubes, cylinders, hemi-spheres and pyramids. Modern compositions are always restricted to a handful of these figures.

In Parametricism all elements of architecture become parametrically malleable. This allows them to be adaptive to each other as well as adaptive to contextual conditions. Instead of repetition institutos de investigación especializados dentro de la arquitectura, son las escuelas, así como también las oficinas de vanguardia, las que tienen que emprender la tarea de investigar y experimentar. Solo a través de la diferenciación entre vanguardia y lo convencional, la arquitectura puede sobrellevar la acelerada demanda por innovación, al mismo tiempo que entregar soluciones que reflejen el estado del arte con respecto a las tareas inmediatas.

-L. F.: «Los límites de nuestro lenguaje de diseño son los límites de nuestro pensamiento de diseño. Cómo representamos la arquitectura, determina cómo anticipamos (diseñamos) la arquitectura. ¿̇Es el Parametricismo la más reciente extensión de nuestros límites de pensamiento arquitectónico y de diseño?

P. Sch.: No, el Parametricismo es un estilo más que un medio de diseño y es el medio de diseño el que define los límites de nuestro pensamiento. Sin embargo, el Parametricismo depende de los nuevos métodos de diseño y es, por lo tanto, el estilo más eficaz para ampliar el universo de posibilidades proporcionadas por estos. Los nuevos medios de diseño digitales han expandido los límites de nuestro pensamiento de diseño: modelamiento de subdivisión de superficies y modelamiento desde NURBS (Non-Uniform Rational B-Splines), sistemas dinámicos (casi físicos) de fluidos, pelo y tejidos (fluids, hair and cloth). Más aún estoy hablando acerca de un universo de modelamiento asociativo.

La idea y posibilidad de programar asociaciones (dependencias) entre las variables de un modelo paramétrico abren un nuevo campo de pensamiento: el pensamiento en términos de variaciones y correlaciones, así como en términos de genotipos que contienen virtualmente una variedad infinita de fenotipos. El estatus y significado de un modelo cambia: es solo un momento efímero o un punto dentro del continuo de posibilidades, el fenotipo de un genotipo subyacente que proporciona la estructura topológica y lógica del modelo.

-L. F.: Si el Parametricismo produce un proceso de diseño más abierto y flexible, ¿̇puede ser reconocido como una forma más democrática de diseñar? ¿̇cuáles son las diferencias con el Modernismo? 
3. Estación Congreso-NordPark Cable Railway. Innsbruck, Austria by Zaha Hadid Architects. Photography Werner Huthmacher.

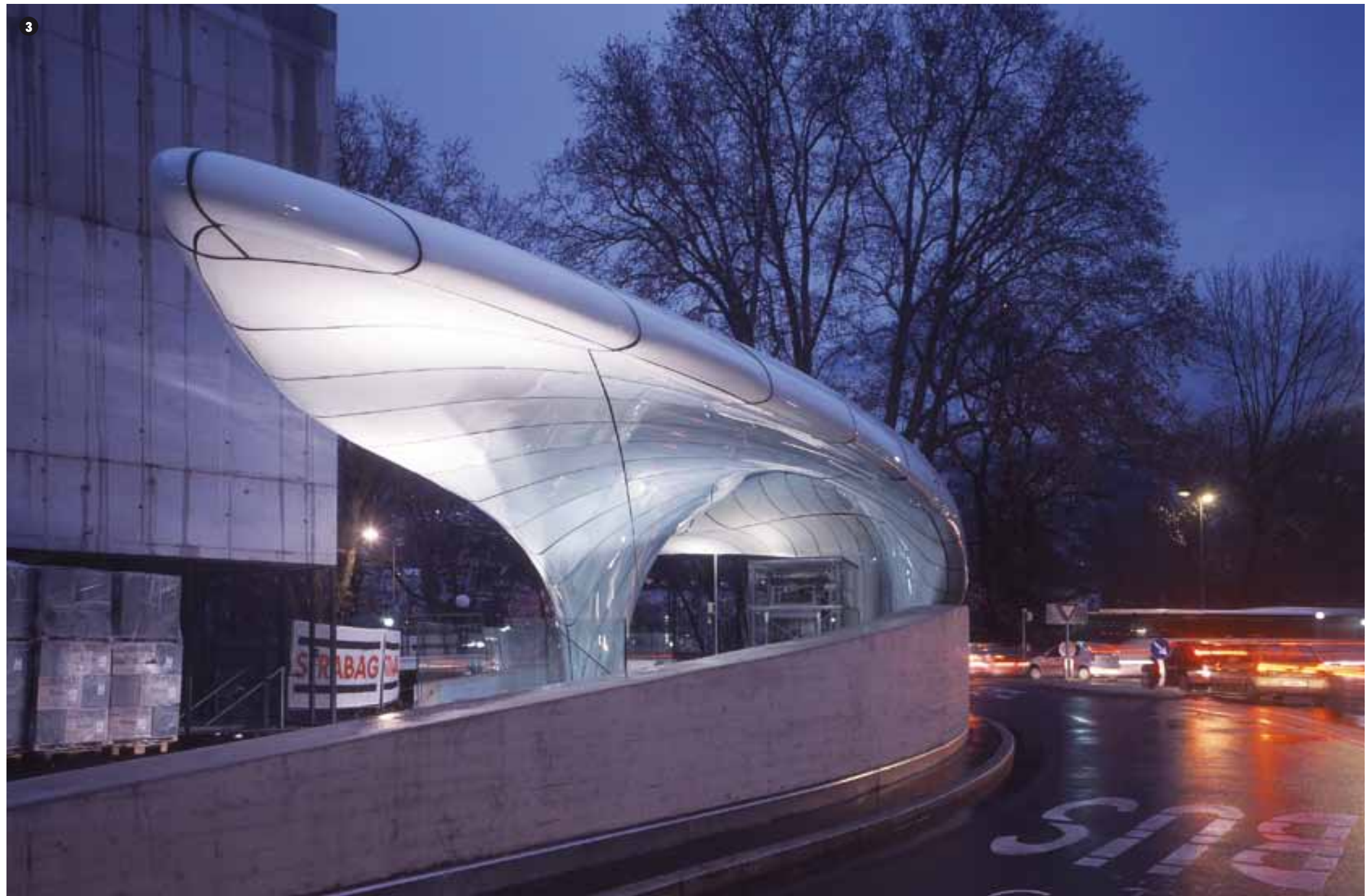

P. Sch.: No diría que el Parametricismo es una forma más democrática de diseñar, sino más bien, una forma más versátil y adaptable. Puede (pero no debe) funcionar desde abajo hacia arriba, es decir, como un proceso emergente, por ejemplo, cuando se usa programación generativa o sistemas basados en agentes. El Modernismo en cambio, es siempre un proceso deliberado, desde arriba hacia abajo, sin importar si se está moviendo por agregación desde adentro o vía substracción y división desde fuera. Sus elementos compositivos primarios son los mismos que los de la arquitectura clásica: figuras geométricas rígidas como cubos, cilindros, esferas y pirámides y sus composiciones, por lo tanto, está siempre restringido a un puñado de estas figuras.

En el Parametricismo, en cambio, todos los elementos pueden ser paramétricamente manejados. Esto les permite adaptarse a los otros elementos así como también a las condiciones de su contexto. En lugar de repetición, este estilo promueve la diferenciación y en lugar de simple yuxtaposición, la correlación. Cada acción convoca una reacción, es decir, la deformación codifica información. Todo esto contribuyó al gran logro del Parametricismo: la intensificación de las relaciones al interior de un edificio y de este con su contexto, lo que responde a la creciente y cada vez más compleja demanda de la sociedad por comunicación.

La sociedad de redes Posfordista está caracterizada por una creciente diversidad y complejidad de los escenarios de comunicación -estado de una sociedad funcionalmente diferenciada-. Permanecer productivo dentro de esta, requiere un nuevo nivel en la intesidad comunicativa de cada individuo. Los flujos deben ser continuamente coordinados y actualizados dentro de una red compleja y la expresión arquitectónica más pertinente es un campo de simultaneidad: es decir, espacios urbanos donde se presente una rica variedad de ofertas comunicacionales. El campo visual 
Parametricism promotes iteration and differentiation. Instead of mere juxtaposition Parametricism promotes correlation. Every action calls forth a reaction. In this way deformation encodes information. All this has contributed to Parametricism's great achievement: the intensification of relations both within the building and between the building and its context. This intensification of relations is architecture's answer to society's increased complexity and increased demand for communication.

Post-fordist network society is characterized by an increased diversity and complexity of communication scenarios. It is the latest/current stage of modern, functionally differentiated society. To remain productive within this society requires a new level communicative intensity from every individual. Everybody's path must be continuously coordinated and updated within a complex network. The pertinent architectural expression of this is the field of simultaneity, i.e. urban spaces where a rich variety of communicative offerings are simultaneously presented. The visual field is layered in all directions, in front, above, below. This rich manifold is ordered according to gradients and laws of correlation so that hidden layers can be inferred from visible layers. Navigation and orientation are key, as well as the atmospheric priming of social interaction. This poses three key aspects of architecture's task, the aspects of organization, articulation and signification, together constituting architecture's core competency. This leads us from modern space to parametric fields.

-L. F.: Considering today's global agenda, How does Parametricism address sustainability issues?

P. Sch.: The ecological challenge referred to above is among the defining moments of our epoch. Its impact on contemporary architecture and urbanism is second only to the challenge posed by the dynamic and complexity of Postfordist Network Society. Indeed, the general paradigm of «eco-systems» applies to both, and is embraced as founding paradigm of Parametricism. The same design concepts, techniques and tools of Parametricism that allow contemporary architects to ramp up the communicative complexity of the built environment are also congenial to the agenda of optimizing architectural forms with respect to ecological performance criteria. Morphological output variables can be programmed to respond to environmental input parameters. For instance, a data-set like a sun exposure map that maps the radiation-intensities a facade is exposed to during a given time period can become the data-input for the adaptive modulation of a sun-shading system. As the system of shading elements wraps around the façade the spacing, shape and orientation of the individual elements gradually transform and adapt to the specific exposure conditions of their respective location on the façade. The result is a gradient, continuously changing façade pattern that optimizes sun-protection relative to light intake for each point on the façade. At the same time, this adaptive modulation gives the building an organic aesthetic that also makes the orientation of the building in the environment legible and thus facilitates the comprehension and navigation of the urban environment. The differentiated articulation of the façade contains and transmits information about its position rather than remaining indifferent and blind. The same principle of conspicuous, adaptive variation and correlation is being applied to the activity and event parameters of the urban life process. The disorientating, generic neutrality and monotony of Modernism gives way to the ecologically adaptive eloquence of Parametricism.

-L. F.: How Architecture can be an autonomous system and at the same time socially innovative?

P. Sch.: Only as autopoietic system can architecture be innovative. That's a fact of history. Before the emancipation of architecture the built environment was reproduced in the uncritical form of tradition bound building. It was suffused in the general reproduction of society and its institutions. At that stage of history -in the era of feudalism- political power, legal power, economic power, ideological power as well as control over the built environment were all together concentrated at the top of a stratified order. The emancipation of architecture emerged together with the emancipation of the other domains that now structure functionally differentiated society, i.e. together with the emancipation of the legal system, the economic market system, as well as science. All these systems are autopoietic systems. Since their emancipation (differentiation) the innovative development of society accelerated. Each system can develop its own dynamic without being held back by the other systems but with the obligation to adapt to each other, each on its own terms, and each finally judged (accepted or rejected) by the others.

-L. F.: Before the launch of Volume I, you conducted a series of lectures for students. Which were the objectives and conclusions of those encounters? Do you aim for the book to be also material of discussion in architectural schools?

P. Sch.: Certainly, the book will be most relevant for those schools of architecture that see themselves as active, creative participants in architecture's progress rather than mere training institutions. The book addresses itself to architecture's avant-garde. This includes the most ambitious students.

The lectures were in fact seminars that allowed for a lot of feedback and questions. I think they were a learning experience for all those who participated including for me. Volume I was finished but the discussions had a certain impact on Volume II which is now also finished.

\section{-L. F: As the main thesis of the books states,} architecture is a closed system that communicates with other subsystems, Do you think that this book will enable our discipline to be understood by others more clearly? Have you received any feedback related to this? está estratificado en todas las direcciones, frente sobre y abajo. Esta multiplicidad está ordenada de acuerdo a gradientes y leyes de correlación, de modo que capas que están escondidas puedan ser deducidas desde las capas visibles. Navegación y orientación son fundamentales, así como también la atmósfera de interacción social, planteando tres aspectos cruciales de la misión de la arquitectura: organización, articulación y significado, que juntos constituyen el núcleo de su competencia como disciplina. Esto nos conduce desde el espacio moderno a los campos paramétricos.

-L. F.: Considerando la agenda global actual, ¿̇cómo aborda el Parametricismo el tema de la sustentabilidad?

P. Sch.: El desafío ecológico está entre los momentos determinantes de nuestra época. Su impacto sobre la arquitectura y el urbanismo contemporáneos se sitúa solo después del desafío planteado por la dinámica y complejidad de la sociedad Postfordista. Ciertamente, el paradigma general de los «sistemas ecológicos» se aplica a ambos, y está considerado como paradigma fundacional del Parametricismo. Los mismos conceptos de diseño, técnicas y herramientas que permiten a los arquitectos contemporáneos intensificar la complejidad comunicacional del medio ambiente construido, son también adecuados a la agenda de optimización de formas arquitectónicas en relación a criterios ecológicos.

Resultados morfológicos variables pueden ser programados para responder a parámetros medioambientales. Por ejemplo, un sistema de datos, como un mapa de exposición solar que entrega las intensidades de la radiación a las que una fachada está expuesta durante un tiempo determinado, puede transformarse en información para la modulación adaptable de un sistema de sombreado: a medida que este sistema envuelve la fachada, la forma, distanciamiento y orientación de los elementos individuales se adapta gradualmente a las condiciones específicas de exposición en cada zona de la fachada. El resultado es un gradiente, un patrón que cambia continuamente para optimizar la protección solar de acuerdo a la entrada de luz. Al mismo tiempo, esto le otorga al edificio una estética orgánica que hace además legible su orientación en el contexto, 
4. Estación Lowenhaus-NordPark Cable Railway. Innsbruck, Austria. Zaha Hadid Architects. Photography Werner Huthmacher.

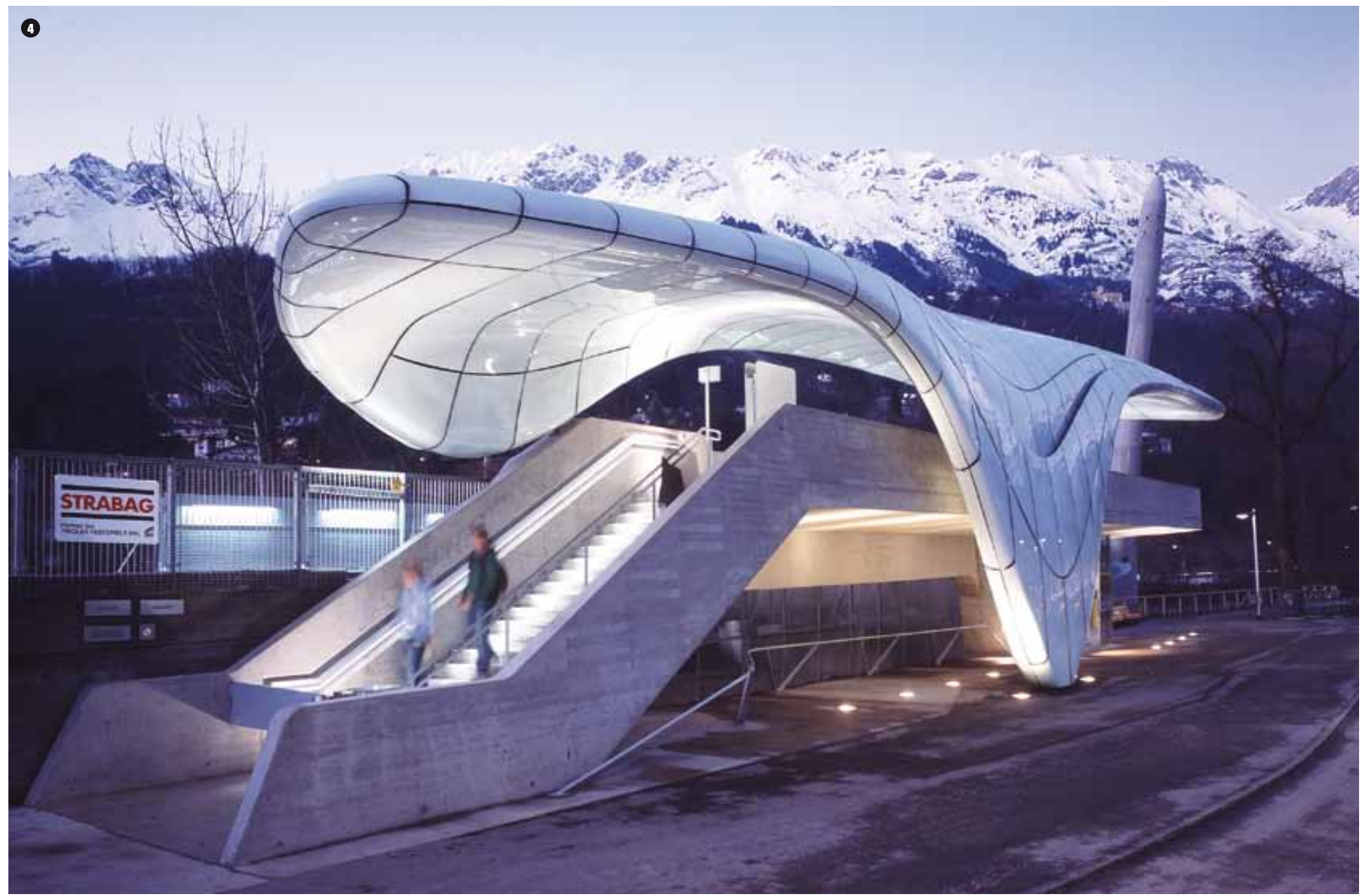

facilitando la comprensión y navegación en el medio ambiente urbano: la fachada contiene y transmite información acerca de su posición en lugar de permanecer indiferente y ciega. El mismo principio está siendo aplicado a la actividad y parámetros del proceso de vida urbano. La desorientación, neutralidad genérica y monotonía del Modernismo da espacio a la elocuencia y adaptación ecológica del Parametricismo.

-L. F.: ¿ Cómo puede la arquitectura ser un sistema autónomo y socialmente innovador al mismo tiempo?

P. Sch.: La arquitectura solo puede ser innovadora siendo un sistema autopoiético. Ese es un hecho histórico. Antes de la emancipación de la arquitectura, el medio ambiente construido fue reproducido sin cuestionamiento de acuerdo a la tradición e inmerso en la reproducción general de la sociedad y sus instituciones. En ese período de la historia -en los tiempos del feudalismo, por ejemplo- el poder político, legal, económico e ideológico así como el control sobre el medio ambiente construido, estaban concentrados en la parte superior del orden jerárquico.

La emancipación de la arquitectura surgió junto a la de los otros dominios que ahora estructuran una sociedad funcionalmente diferenciada. Todos estos sistemas son autopoiéticos y desde ese momento de diferenciación, el desarrollo de la sociedad se aceleró. Cada sistema puede desplegar su propia dinámica sin estar subordinado a los otros, pero con la obligación de adaptarse entre sí, sobre la base de sus propios términos, para ser finalmente juzgado (aceptado o rechazado) por el resto.

-L. F.: Antes del lanzamiento del Volumen I, usted realizó una serie de charlas para estudiantes. ¿ Cuáles fueron los objetivos y conclusiones de esos encuentros? ¿̇Aspira usted a que su libro sea material de discusión en las escuelas de arquitectura?

P. Sch.: Ciertamente, el libro será más relevante para aquellas escuelas que se ven a sí mismas como participantes activos y creativos en 
7. Vista Galaxy Soho, Beijing. Zaha Hadid Architects.

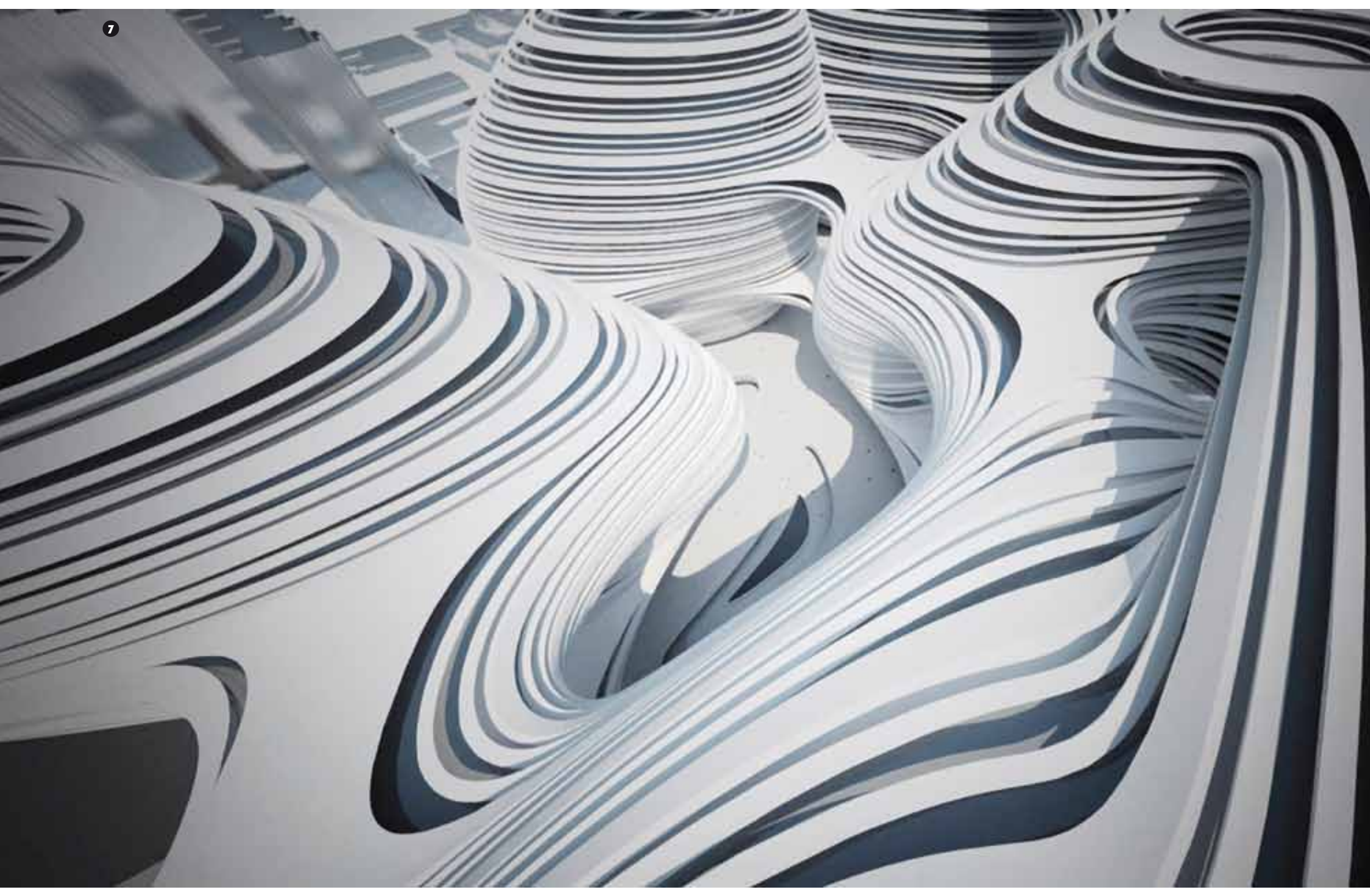


P. Sch.: I think the internal discourse within architecture is most important. However, it would be beneficial if our closest collaborators -the engineering disciplines that contribute within our design teams- would get a better sense of architecture's specific raison d'etre and societal function in distinction to their own role and concerns. Further one might hope that some interest develops in the broad field of cultural studies and cultural history. For me personally recognition within sociology would give me a lot of satisfaction. After all, the book contains a kind of sociologically informed discourse analysis of the discipline as societal function system. Sociologists could very well be interested. In fact, shortly after the publication of Volume I, I have been engaged in a long e-mail correspondence with the German sociologist Dirk Baecker. Baecker is sympathetic and spent time to read and discuss my ideas. After hard arguments, it seems, I could convince him of the general thrust of my account of architecture. His judgment is especially interesting as he was one of Luhmann's closest disciples and remains one of his most potent and original followers.

-L. F: "The Autopoiesis of Architecture», Volume Il will be available this autumn. Can you give us an advance outline of the main issues that will be addressed in this second part? Did you make any change or include new topics after the feedback from Volume I?

P. Sch.: Volume I-subtitle: A New Framework for Architecture- introduces a new theoretical framework within which architecture may analyze and confront itself in terms of its most fundamental concepts, methods and values. Volume II -subtitle: A New Agenda for Architecture- continues to analyze architecture's discourse and proposes a new agenda for contemporary architecture in response to the challenges and opportunities posed by current societal and technological developments. The Volume ends with a manifesto for the new style of Parametricism, promoted as candidate to become the unified, epochal style for the $27^{\text {st }}$ century. The theory of architectural autopoiesis is a reflection-theory or self-description of architecture formulated from within architecture. As such its purpose is to contribute to the necessary selfsteering of the autopoiesis of architecture. Like all reflection theories -e.g. economic theories, jurisprudence, the epistemologies formulated within science, political theories etc - the theory of architectural autopoiesis oscillates between descriptive and normative modes of theorizing. By necessity, as committed inside communication, it is simultaneously a descriptive and a normative theory By describing, conceptually systematizing, and reconstructing the rationality of architecture's history and current state, the theory gathers the necessary internal connectivity to make normative claims el progreso de la arquitectura más, que simplemente instituciones de capacitación. El libro está dirigido a la vanguardia de la arquitectura; esto incluye a los estudiantes más ambiciosos.

Acerca de las charlas, estas fueron de hecho seminarios que permitieron una gran cantidad de retroalimentación y preguntas. Creo que fueron una experiencia de aprendizaje para todos aquellos que participaron, incluyéndome. El Volumen I estaba terminado, pero las discusiones tuvieron cierto impacto en el Volumen II, el cual acaba de ser terminado.

-L. F.: Como establece la tesis principal del libro, la arquitectura es un sistema cerrado que se comunica con otros sistemas. ¿Piensa usted que este libro permitirá que nuestra disciplina sea entendida más claramente por otras disciplinas? ¿Ha recibido algún comentario al respecto?

P. Sch.: Creo que el discurso interno dentro de la arquitectura es más importante. No obstante, sería beneficioso si nuestros colaboradores más cercanos -como los ingenieros que forman parte de nuestros equipos de diseño- obtuvieran una mejor idea de la razón de ser y la función social de la arquitectura a diferencia de sus propios roles y preocupaciones. Más aún, uno podría esperar que algún interés se desarrollara en el amplio campo de los Estudios Culturales e Historia de la Cultura.

Personalmente, el reconocimiento dentro de la sociología me daría mucha satisfacción. Después de todo, el libro contiene una especie de análisis sociológicamente informado acerca de la arquitectura como disciplina, así es que los sociólogos podrían estar interesados. De hecho, poco después de la publicación del Volumen I, comencé una extensa correspondencia electrónica con el sociólogo alemán Dirk Baecker. Él se tomó el tiempo de leer y discutir mis ideas y después de duros debates, pude convencerlo -al parecer-de mis ideas generales acerca de la arquitectura. Su juicio es especialmente interesante porque él fue uno de los discípulos más cercanos de Luhmann y aún se mantiene como uno de sus seguidores más potente y original.

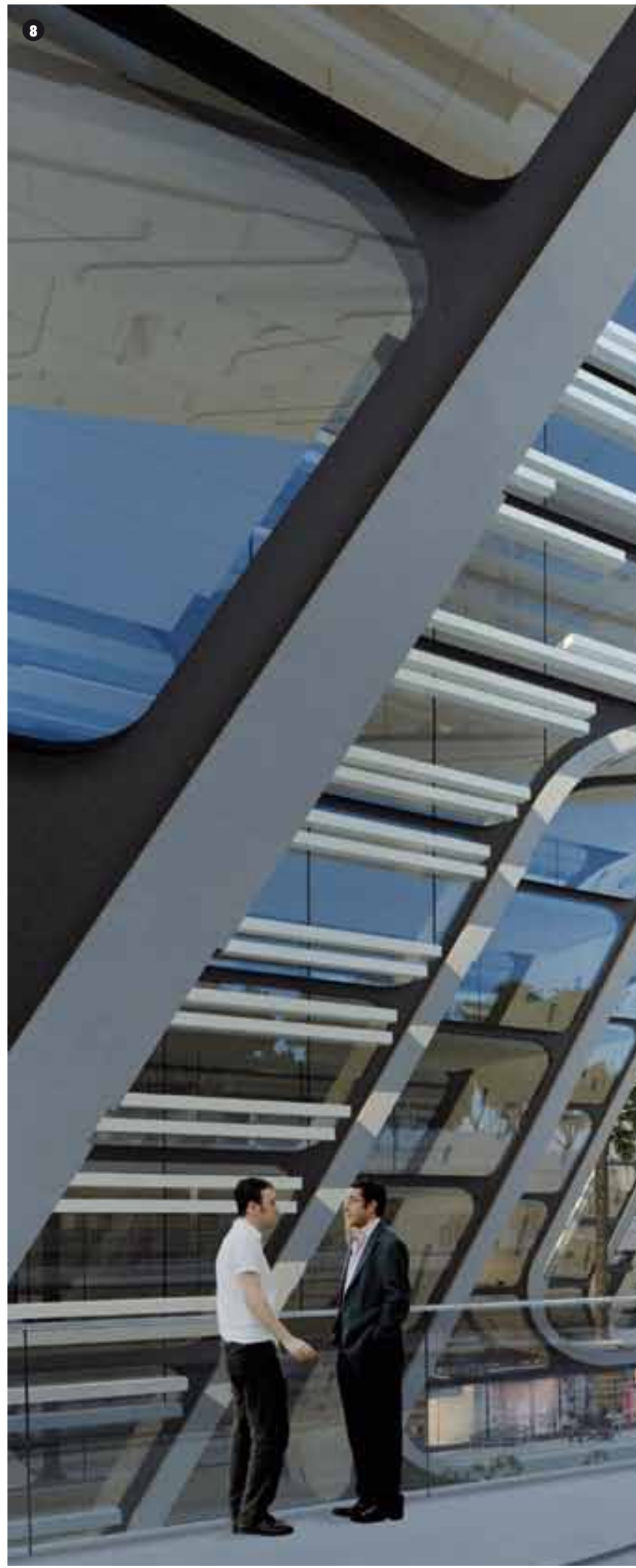




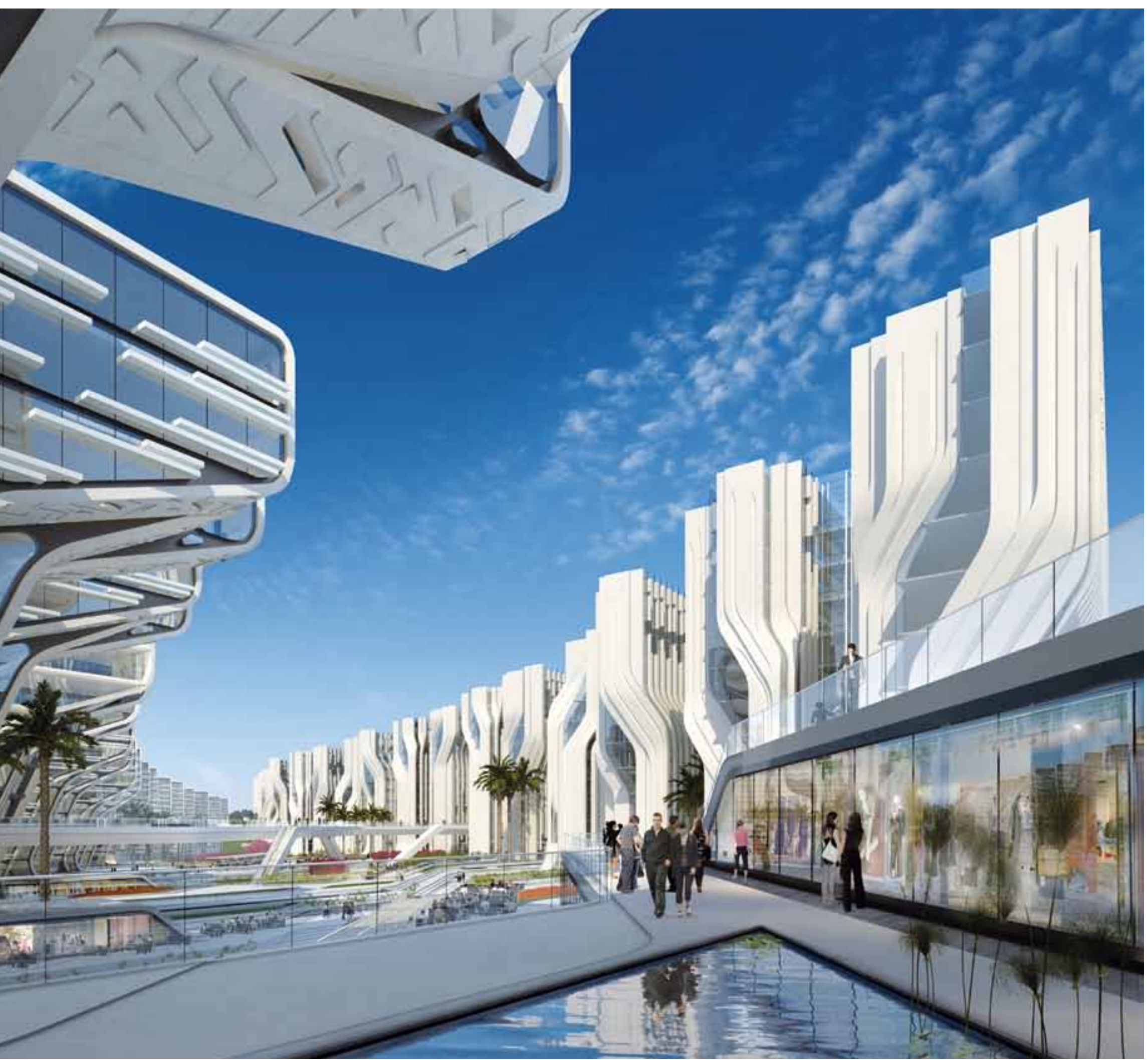


and projections plausible. The tension between descriptive and normative moments permeates the totality of «The Autopoiesis of Architecture». However, the balance between the two moments is struck differently in the two Volumes. From Volume I to Volume II, as we move from framework to agenda, the balance shifts towards the normative pole, and indeed includes more projective, speculative moments.

The manuscript of Volume II was closed early this year. Therefore there was not much time to react to criticisms. However, some of the feedback I got in response to Volume I allowed me to clarify and reinforce some points. But no fundamental challenge emerged that made me change my position. Critique mostly focused on Parametricism. Some critics regretted that I did push Parametricism within my general theoretical treatise. It is true that, as a general theory of architecture, the theory of architectural autopoiesis could be separated from Parametricism and indeed has value independent from any commitment to Parametricism. However, for me, the references to Parametricism afford an important (contingent but compelling) concretization. Theories need to be fertile, they must be probed and driven to make a difference for design practice, i.e. they have to intervene in the debate about the future direction of architecture. In Volume II the commitment to Parametricism becomes even more prominent and explicit, also offering specific guidance for the further innovative development of Parametricism. But, once again most of the insights and arguments unfolded in Volume II can be appreciated and upheld without buying into my commitment to Parametricism.

Patrik Schumacher, The Autopolesis of ArCHITECTURE Volume I. A New Framework for ArChitecture, John Wiley \& Sons, London, 2011
-L. F.: «La Autopoiesis de la arquitectura», Volumen II estará disponible este otoño. ¿Podría darnos un avance de los principales tópicos que serán abordados en esta segunda parte? ¿े Ha hecho algún cambio o incluido nuevos temas después de la recepción crítica del Volumen I?

P. Sch.: El Volumen I-subtitulado: Un Nuevo Marco de Trabajo para la Arquitecturaintroduce un nuevo marco teórico dentro del cual la arquitectura puede analizar y confrontarse en términos de sus conceptos, métodos y valores fundamentales. El Volumen II -subtitulado: Una Nueva Agenda para la Arquitectura- continúa analizando el discurso arquitectónico y propone una nueva agenda en respuesta a los desafíos y oportunidades generados por el actual desarollo de sociedad y tecnología. Este volumen finaliza con un manifiesto del nuevo estilo, el Parametricismo, promovido como candidato a transformarse en el estilo unificador del siglo XXI.

La teoría de la autopoiesis arquitectónica, es una teoría-reflexión o autodescripción de la arquitectura formulada al interior de la misma. Como tal, su objetivo es contribuir a la autodirección de esta y como toda teoría de reflexión -la teoría económica, la jurisprudencia, la epistemología de la ciencia y las políticas teóricas- oscila entre modos descriptivos y normativos. Por medio de la descripción, conceptualización, sistematización y reconstrucción de la racionalidad de la historia de la arquitectura y su estado actual, la teoría reúne la conectividad interna necesaria para hacer demandas normativas y proyecciones plausibles. La tensión entre los momentos descriptivos y normativos se extiende en la totalidad de «La Autopoiesis de la Arquitectura». Sin embargo, el balance entre los dos momentos es diferente en los dos volúmenes. Desde el
Volumen I al II, a medida que nos movemos desde el marco de trabajo hacia agenda,el balance se inclina hacia el polo normativo e incluye efectivamente más especulaciones y proyecciones.

El manuscrito del Volumen II fue terminado a principios de este año, por lo tanto, no hubo mucho tiempo para reaccionar a las críticas. No obstante, algunos de los comentarios al Volumen I me permitieron clarificar y reforzar algunos puntos, pero no hubo ningún cuestionamiento fundamental que haya hecho cambiar mi postura.

La crítica se focaliza en el Parametricismo: algunos críticos rechazan el que lo haya promovido dentro de mi tratado. Es cierto que, como teoría general de arquitectura, la autopoiesis puede ser separada del Parametricismo y tener un valor independiente de cualquier compromiso con este. Sin embargo, para mí, las referencias a este estilo proporcionan posibilidades concretas (inciertas pero convincentes). Las teorías necesitan ser fértiles, deben ser exploradas y conducidas para hacer diferencia en la práctica de diseño; esto significa que tienen que intervenir en el debate acerca de la dirección futura de la arquitectura. En el Volumen II, el compromiso con el Parametricismo se vuelve aún más explícito, ofreciendo además una guía específica para un desarrollo más innovador. Pero, una vez más, la mayor parte de los puntos de vista y argumentos expuestos pueden ser apreciados y defendidos sin adherir a mi compromiso con el Parametricismo.

Patrik Schumacher, LA AUtOPOIESIS DE LA ARquitectura, Volumen I. Un NUEVO marco de TRABAJO PARA LA ARQUITECTURA, John Wiley \&Sons, Londres, 2011. 


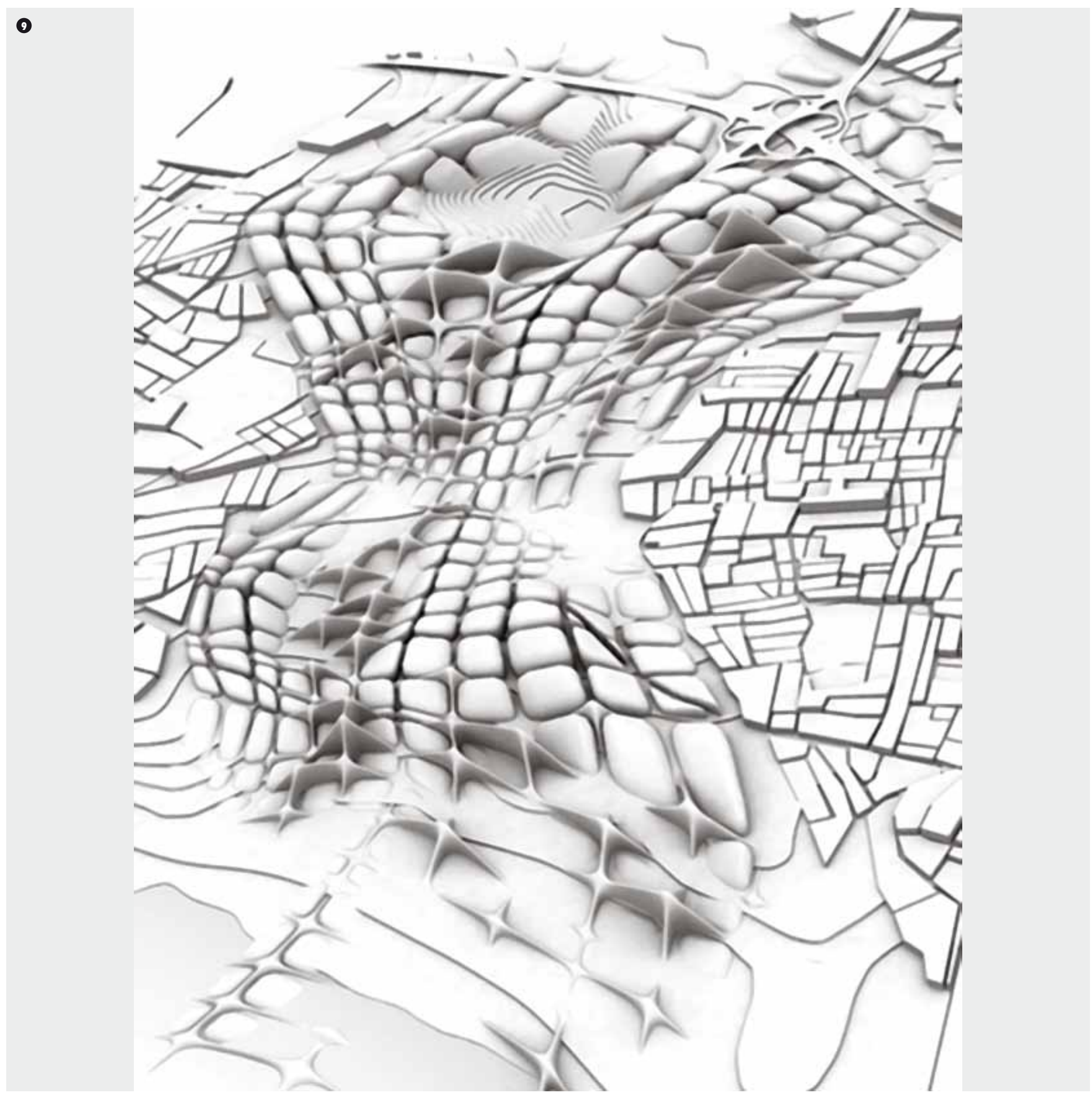

